\title{
Social Inclusion and Exclusion in GCC Labour Policy Transformations: Evidence from Qatar and Saudi Arabia
}

\author{
Ahmed Aref \\ ${ }^{1}$ Correspondence: Ahmed Aref, Institute for Policy Research, Department of Social and Policy Sciences, \\ University of Bath, UK. E-mail: a.aref@bath.ac.uk
}

Received: December 22, 2020

Accepted: January 19, 2021

Online Published: March 11, 2021

doi:10.5539/jpl.v14n2p124

URL: https://doi.org/10.5539/jpl.v14n2p124

\begin{abstract}
Over the past five years, labour policies in the countries of Gulf Cooperation Council (GCC) have witnessed significant transformations driven by numerous macro-level challenges, such as demographic imbalance, dependence on hydrocarbon economy, political and security crises. Despite the challenges' commonality across the GCC, yet, policy responses related to labour were different from country to another.

This article explores the macro-level challenges facing labour policymaking in the GCC, followed by an examination of social inclusion/exclusion patterns targeting expatriate workers in Qatar and Saudi Arabia due to the recent labour policy transformations. Both countries were selected to provide in-depth contextual analysis of the radical shift towards inclusion in Qatar and exclusion in Saudi Arabia.
\end{abstract}

Keywords: social inclusion/exclusion, GCC labour policies, Kafala system, labour market structure and migrant labour rights

\section{Introduction}

Since the discovery of oil in the Arabian Gulf in the 1930s, migration has played a significant role in the development of the six GCC countries (Bahrain, Kuwait, Oman, Qatar, Saudi Arabia, and the United Arab Emirates UAE). The lack of labour absorption in the local market has generated the need for human capital importation to support GCC's domestic development. As a result, oil discovery is considered the catalyst behind migration mobility to the GCC (Errichiello, 2012). Accordingly, as a direct impact of extensive labour migration to the Gulf, a demographic imbalance has emerged in the six countries with some variation from one country to the other. In total, recent statistics show that 51 percent of the total Gulf population are nationals, and 49 percent are expats. The demographic imbalance is extreme in countries like Qatar and the UAE, as nationals represent only 10.1 and 11.5 percent of the population, respectively. At the same time, it is less severe in other GCC countries like Saudi Arabia, where nationals represent 67.3 percent of the population (EUI Migration Policy Center \& Gulf Research Center, 2016).

Despite the formal recognition of the contribution of expats to GCC local economies, the demographic imbalance has remained a key factor in how GCC governments have designed social policies. This imbalance obsession maintained the embedding of structural social exclusion for decades. The exclusion is caused by the explicit privileges granted exclusively to nationals. From a GCC policy maker's perspective, the Kafala (sponsorship) system is designed to regularise migrant labour based on 'rotating' and 'temporary' residence. Justified by the demographic imbalance and attempts to protect nationals, the GCC governments have restricted the rights of migrants by allowing only temporary migration with no pathways to permanent residence or citizenship and the rights that these classifications entail. Accordingly, the Kafala system implicitly supports exploitative labour relations between expatriate workers and their Kafeels (sponsors) (Babar \& Gardner, 2016).

However, in reality, some expats, especially skilled labour, remain in the country on 'renewable' temporary residence for decades. In some cases, second and third generations of expats call the GCC home. Consequently, from a social justice perspective, deprivation of these expats from such socioeconomic privileges can be perceived as social exclusion. Besides the social justice aspect, the Kafala system has been heavily criticised by both international bodies and literature as a system that regulates systematic abuse of expatriate labour rights (Bandirali, 2018).

There exists a research gap related to examining social inclusion and exclusion in the social policies of the GCC. 
Instead, the literature on migration in the GCC focuses on exploring working conditions, examining the effectiveness of the Kafala system, and understanding the impact of expats' remittances on family wellbeing in home countries. Thus, very few studies have looked at aspects of social inclusion/exclusion in the GCC, such as the attitudes of nationals towards expats and its effect on migration policies (Diop et al., 2017). Furthermore, these studies have not provided any in-depth analysis of the past and current social policies as a tool for adding depth to our understanding of the driving forces behind social inclusion/exclusion in the GCC.

Over the past five years, GCC social policies in general and labour policies, in particular, have witnessed rapid developments. These developments represent a policy response to two major recent challenges, which are: (I) falling oil prices in 2014 (Nusair, 2016), and (II) the GCC political crisis, which started in June 2017 when Saudi Arabia, UAE, Bahrain and Egypt cut off their diplomatic ties with Qatar (Naheem, 2017). The first challenge led to negative economic repercussions on all GCC economies as did the regional arms race that ensued following the second.

Indeed, labour policy developments in the past five years have been extensively mapped in the literature from legal perspectives. However, social inclusion and exclusion of expatriate workers in these policy transformations remains an under-researched area in Gulf studies. This research gap will be addressed by mapping and analysing the social inclusion and exclusion trends in the recent GCC transformations related explicitly or implicitly to the labour policies. A critical overview will be provided of the macro level political, demographic, and socioeconomic challenges facing the six GCC countries within the policymaking process, with an emphasis on contemporary challenges. Subsequently, an examination of how these policy transformations have structured social inclusion/exclusion in Qatar and Saudi Arabia will ensue. The selection of both countries was based on their extreme policy contrasts. Qatar provides a clear case of policy transformation towards inclusion, while Saudi Arabia has introduced a set of policies favoring exclusion. Hence, this study will attempt not only to map the social inclusion/exclusion trends in both countries but also to understand the root causes and driving forces that has led these similar GCC countries down differing paths.

\section{Method}

Literature refers to social inclusion and social exclusion as political concepts rather than being analytical ones. In fact, there are numerous theoretical foundations behind social inclusion/exclusion, such as theory of social capital, social cohesion, social stratification, and theories of social justice, where inclusion/exclusion are looked at from discrimination and inequality perceptions. The hypothetical concern is that social inclusion/exclusion has been conceptualized as dichotomy, either you are in or out, which forms a static assumption and raises the need for a dynamic theory (Øyen, 1997).

In fact, literature identifies several driving forces behind social inclusion/exclusion, including race, nationality, ethnicity, identity, religion, social class, gender and/or a mixture of multiple root causes. The application of social inclusion/exclusion concept in labour policies is usually associated with economic and power inequalities and how high orders of political systems shape labour structure (Labonte, 2004).

Hence, a 'realist review' will be employed, thus liberating the space for examining social inclusion/exclusion in the labour structure within a complex social context of the GCC (Clegg, 2005). The purpose of a realist review is to provide a critical understanding of how and why policies impact different beneficiaries, either explicitly or implicitly (O'Campo et al., 2015). This method usually goes beyond the descriptive narrative, providing a larger degree of contextual analysis in order to make possible a deeper understanding of the problem within a complex social system. The rationale for selecting this method is due to the below characteristics: (Lawrence et al., 2012; Moher et al., 2015; Pawson et al., 2005)

A. The difficultly of assessing social inclusion/exclusion in labour policies in the Gulf context. This is due to the complexity of the social system, taking into account the extraordinary legal framework of the Kafala system, the extreme demographic imbalance, the socioeconomic challenges related to the sustainability of a rentier state model, contemporary security challenges including the recent GCC crisis with Qatar, Gulf identity dilemma, the tribal society, strict social stratification, structural inequality between nationals and expats, difficult-to-attain social mobility, and the reflection of all these fundamentals within policy transformations.

B. A realist review does not provide simple answers to complex questions. It will not tell policymakers whether something works or not. In contrast, it aims to understand a complex social issue. Hence, the article does not provide policy recommendations, nor answers to a question of what it means for an expatriate worker to be socially included or excluded in the Gulf. However, it provides a situation analysis to capture the macro and meso portraits of social inclusion/exclusion in the labour policy transformations. 
C. The realist review provides the space for legislative mapping as well as grey literature analysis, which is necessary in the research construction to capture the rapid transformations in labour policies over the past five years in Saudi Arabia and Qatar.

D. The realist review method enables the writer to pursue critical analysis, exploring how and why different actors adopted different approaches in similar contexts, which is the case of a social inclusion trend in policy transformation in Qatar, and a social exclusion trend in Saudi Arabia.

\section{Challenges Facing Social Policymaking in the GCC}

This section outlines the understanding of the broad challenges facing the social policymaking process in the GCC from a macro level perspective. The analysis includes both the contemporary and abiding structural challenges that determine the social policymaking process in general and labour policies in particular.

\subsection{Demographic Challenge: Imbalance as an Abiding Policy Debate}

The demographic imbalance is one of the fundamental abiding challenges in the GCC. The demographic debate has been ongoing for decades within Gulf academic and policymaking circles.

Although the migration phenomenon and its demographic consequences have been extensively studied from multidisciplinary perspectives in the GCC, yet the segregated data and detailed statistics are not well developed. Hence, a significant body of literature characterises the official demographic statistics in the GCC as insufficient and unreliable (Spiess, 2010). The political sensitivity of publicly declaring the very low and declining percentages of nationals within the total population could be one of the reasons behind the lack of official data. Perhaps, this revelation would raise a debate on distributional politics, excluding the majority of the population (Babar, 2015) and showcase the need for equitable integration policies (Modarres, 2010). Therefore, despite the availability of population data by the 'GCC Statistical Center (GCC STAT)' - which is the most reliable source of official data in the GCC, the specific numbers and percentages of nationals versus expats are not published in case of Qatar and the UAE (GCC-STAT, 2018).

The table and graph below show the updated figures related to the number and percentages of nationals and expats in the GCC countries, which has been calculated by the European University Institute - Migration Policy Center and Gulf Research Center (2016) based on national censuses between 2010 and 2016.

Table 1. Total population and percentage of nationals and expats in the GCC $(2010-2016)$

\begin{tabular}{lllllll}
\hline \multirow{2}{*}{ Country } & Date/ Period & Total Population & Nationals & Expats & \multicolumn{2}{c}{ \% in Total Population } \\
\cline { 6 - 7 } & & & & & Nationals & Expats \\
\hline Bahrain & mid-2014 & $1,314,562$ & 630,744 & 683,818 & 48.0 & 52.0 \\
Kuwait & 31 Mar 2016 & $4,294,171$ & $1,316,147$ & $2,978,024$ & 30.6 & 69.4 \\
Oman & 20 Apr 2016 & $4,419,193$ & $2,412,624$ & $2,006,569$ & 54.6 & 45.4 \\
Qatar & Apr 2015 & $2,404,776$ & 243,019 & $2,161,757$ & 10.1 & 89.9 \\
Saudi Arabia & mid-2014 & $30,770,375$ & $20,702,536$ & $10,067,839$ & 67.3 & 32.7 \\
UAE & mid-2010 & $8,264,070$ & 947,997 & $7,316,073$ & 11.5 & 88.5 \\
Total & & $\mathbf{5 1 , 4 6 7 , 1 4 7}$ & $\mathbf{2 6 , 2 5 3 , 0 6 7}$ & $\mathbf{2 5 , 2 1 4 , 0 8 0}$ & $\mathbf{5 1 . 0}$ & $\mathbf{4 9 . 0}$ \\
\hline
\end{tabular}

Source: European University Institute - Migration Policy Center \& Gulf Research Center (2016). Gulf Labor Markets and Migration (GLMM) Demographic and Economic Database. 


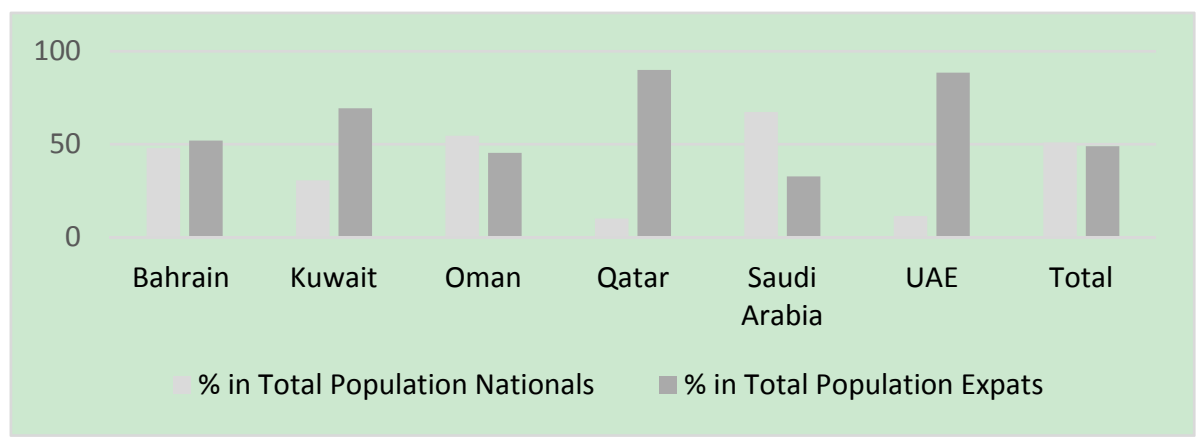

Graph 1. Percentage of nationals and expats in the GCC (2010 - 2016)

Source: Graph extracted from the data shown in table (1) based on same source: European University Institute Migration Policy Center \& Gulf Research Center (2016). Gulf Labor Markets and Migration (GLMM) Demographic and Economic Database.

The data shows that the GCC countries, in general, are facing a demographic imbalance of different intensities between nationals and expats. In Saudi Arabia, the percentage of nationals from the total population is $67.3 \%$ while in Bahrain and Oman, the nationals are about 50\%. Other countries have a more extreme demographic imbalance like the United Arab Emirates, where nationals are 11.5\%, and Qatar where nationals represent only $10.1 \%$ of the total population.

This demographic imbalance is a by-product of the development of the GCC states, as expats have not only contributed to transforming oil wealth into wellbeing for its citizens but have also established the foundations of post-oil economies (Fargues, 2011). However, this imbalance represents a significant dilemma for social policy design and implementation. From the state perspective, the cost of the socioeconomic privileges granted exclusively to nationals cannot be extended to the whole or majority of the population due to the demographic imbalance. However, from a human rights perspective, this discourse structurally undermines the concepts of equality, social justice, and social inclusion (Aref, 2018). According to UN ESCWA, the foreign workers in the GCC are generally excluded from citizenship and formal democratic rights (ESCWA, 2007). This exclusion, among other factors such as the lack of naturalisation paths and the low levels of intermarriages between nationals and expats, has led to the growth of two independent populations in the GCC (Fargues, 2011).

\subsection{Economic Challenge: Dependence on Hydrocarbon Sector and Volatility of the Global Market}

Energy is the primary source of income for the GCC and defines the geostrategic strength of the region and its countries (Dagher, 2014). Since the discovery of oil and natural gas in the Gulf, the GCC economies have been heavily dependent on the hydrocarbon sector (Callen et al., 2014). Not only do energy resources play a critical role in GCC development, but they also create extreme economic dependency, resulting in susceptibility to any volatilities in oil and gas markets (ElGindi, 2016). According to the International Monetary Fund data from 2016, fiscal oil revenue represents 77.5 percent of the total government revenue in the GCC as a whole, while the nonoil revenue represents only 22.5 percent. These percentages vary from one country to another ranging from a regional low of 60 percent in the UAE to as high as 87 percent in Oman, as shown in the below graph (2) (IMF, 2016).

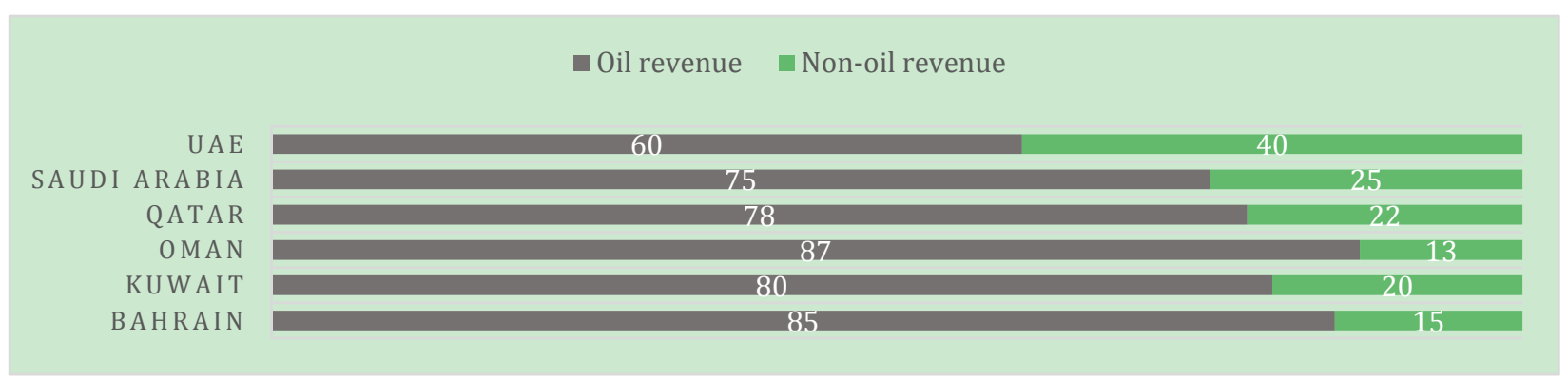

Graph 2. Oil and non-oil fiscal revenue: Percent of total government revenue

Source: IMF (2016). Economic Diversification in Oil-Exporting Arab Countries: Annual Meeting of Arab Ministers of Finance. International Monetary Fund. 
Over the past two decades, the political discourse in the GCC has favored declaring a strategic objective to shift the economies from oil-based to knowledge-based. The six GCC countries announced national visions or strategies, including a formal statement of this objective over the past two decades. Since 2000, this objective turned into a regional commitment agreed upon at the GCC leaders' summit that took place in Manama that year. The 2000 Manama Declaration mentions that "prior attention should be paid to achieving an economy based on technology and knowledge particularly in the fields of information, communication, and ecommerce, and that these sectors would be the basis for economic prosperity" (Alasfoor, 2007). However, the GCC countries are still dependent on the hydrocarbon sector today. They continue to struggle with major structural impediments that hinder their economic diversification, including the rentier state model of development and human capital development challenges (Mishrif \& Al-Naamani, 2018).

Non-diversification of economic resources in the GCC causes a vulnerability in terms of relying on the global market. Hence, one of the most important contemporary challenges facing the GCC was the global oil price reduction that started in the second half of 2014, which shook their economies. Oil proceeds usually account for more than $80 \%$ of GCC government revenues, and over $90 \%$ of Saudi Arabia's budget before the crisis (Vohra, 2017). Indeed, the GCC region as a whole lost $20 \%$ of its combined GDP (US\$340b) in 2015, owing to lower oil prices. Moreover, evidence confirmed the considerable impact of the oil price reduction on the GCC economies in terms of budget deficits, decreased economic growth, and recession in the Real-estate, Hospitality and Construction (RHC) sector (Ernst \& Young, 2016).

The negative consequences of the global oil price reduction put the sustainability of the GCC model of the economy under critical examination. There have been several policy responses to this crisis. One of the immediate responses of GCC countries was substantial budget cuts in governmental expenditures, along with large-scale deportations of expats from various sectors.

\subsection{Political Challenge: The Rentier States to sustain Cradle to Grave Welfare Systems}

The GCC regimes and the societies they govern are traditional, where traditionalism refers to the tribal social structure and Islam as the basis of politics. Such traditional legitimacy has led to accepted personalised rule by tribally-based elite families (Gause et al., 1994).

Much research attempts to understand the complexity of sustainable legitimacy in the GCC. According to AlBaridi (2016), this legitimacy is based on a triad of synergistic machinery: (I) a social contract between the royal families and nationals, (II) inherited national identity associated with granted rights, and (III) a politicised economy characterised by the 'resource curse', where the elites of oil wealth countries tend to curb political rights for the economic wellbeing of the citizens (Al-Baridi, 2016).

According to this political and socioeconomic context, the GCC states are classified in the literature as rentier monarchies, where they manage to develop an unsustainable equilibrium between economic accomplishments and distribution of wealth to the nationals (Springborg, 2013). This setup produces an inherited belief among nationals that the socioeconomic privileges are natural rights and should be continuously granted by the state.

Within this structure, the setup of such a social contract involves embedding social exclusion of expatriates. The contract is exclusive between two parties: royal families, who are governing the GCC states on one side, and the nationals who are benefiting from the redistribution of hydrocarbon wealth. Accordingly, the majority of the GCC population, who are the expatriates, are deprived of the socioeconomic privileges granted to nationals. However, the expatriates still benefit from the economic model of free-taxation, including their salaries, which could be seen as an additional economic burden on the GCC states (Hertog, 2014).

The contemporary challenges in terms of external factors and their impact on the Gulf states put this political economy model of cradle-to-grave welfare system under serious reconsideration. The survival of such a model is critical not only because of the question of ability to continue to pay for such privileges following the global oil price reduction, but also to sustain political silence after the Arab Spring (Bellin, 2012). The changes that took place in neighbouring Arab countries made some GCC countries feel threatened by domestic dissidents that had the potential to be inspired by the Arab Spring (Berger, 2014). Bahrain is one example where a spontaneous uprising in the Arab Spring of 2011 was rapidly and aggressively countered through the support of Saudi Arabia, which feared a sweeping wave of rebellion (Kamrava, 2012). Post-uprising punishments imposed by the Bahraini government, including imprisonments, deaths and revocation of citizenship, constituted threatening messages to potential protestors (Davis, 2016).

\subsection{Security Challenge: GCC Political Crisis and Arms Race}

On 05 June 2017, based on accusations against Qatar of terrorist financing, a coalition of four countries led by 
Saudi Arabia that included three neighbouring Gulf states (Saudi Arabia, UAE and Bahrain) in addition to Egypt, cut off their diplomatic ties with Qatar, escalating a multi-dimensional political, socioeconomic, and security crisis in the Gulf (Naheem, 2017). The Qatari citizens residing in the three abovementioned GCC countries were given two weeks to return to their home countries. At the same time, diplomats were asked to leave within forty-eight hours. The four countries banned Qatar aeroplanes and ships from passing through their airspace and sea routes. Besides, Saudi Arabia closed the only land crossing with Qatar (Rossi, 2018).

A body of literature has emerged after this crisis to examine its impact from different perspectives, such as implications on regional security (Kristian Coates Ulrichsen, 2017), the transformation of political alliances and foreign policies (Wahyuni, 2018), the socioeconomic consequences (Kristian C. Ulrichsen, 2018), the roles of regional powers like Iran and Turkey (Aras \& Akpınar, 2017), the effectiveness of regional mediation by Kuwait and the role of United States (Azzam \& Harb, 2018), and the role of media and soft powers (Fernandez, 2018).

The extensive literature produced to examine the different aspects of the crisis raises the question of values in policy evaluation. The presented evidence has not been isolated from the political and popular discourses in the GCC (Taylor, 2016). The literature mentioned above, and elsewhere, have been to some extent politicised. For example, while some of the publications address the crisis using the term 'boycott', which is the formal language used by the four countries, others describe it as a 'blockade' crisis, which is used in the official political discourse of Qatar.

The crisis contributed, among other factors such as Saudi Arabia and the UAE's intervention in Yemen, to a rapid arms race in the Gulf. According to a recent IHS Markit report, increasing military budgets in Saudi Arabia, and UAE would result in an expected \$100 billion being spent on defence by the GCC in 2019 alone (Alaraby, 2018). As per the military expenditure database of 2018 by the Stockholm International Peace Research Institute (SIPRI), Saudi Arabia is ranked the third country in the share of world military expenditure of the top 15 states with the highest spending as shown in graph (3) (SIPRI, 2018). In another recent report of SIPRI, Saudi Arabia is ranked the world's largest arms importer in 2014-18, with an increase of 192 percent compared to 2009 (SIPRI, 2019).

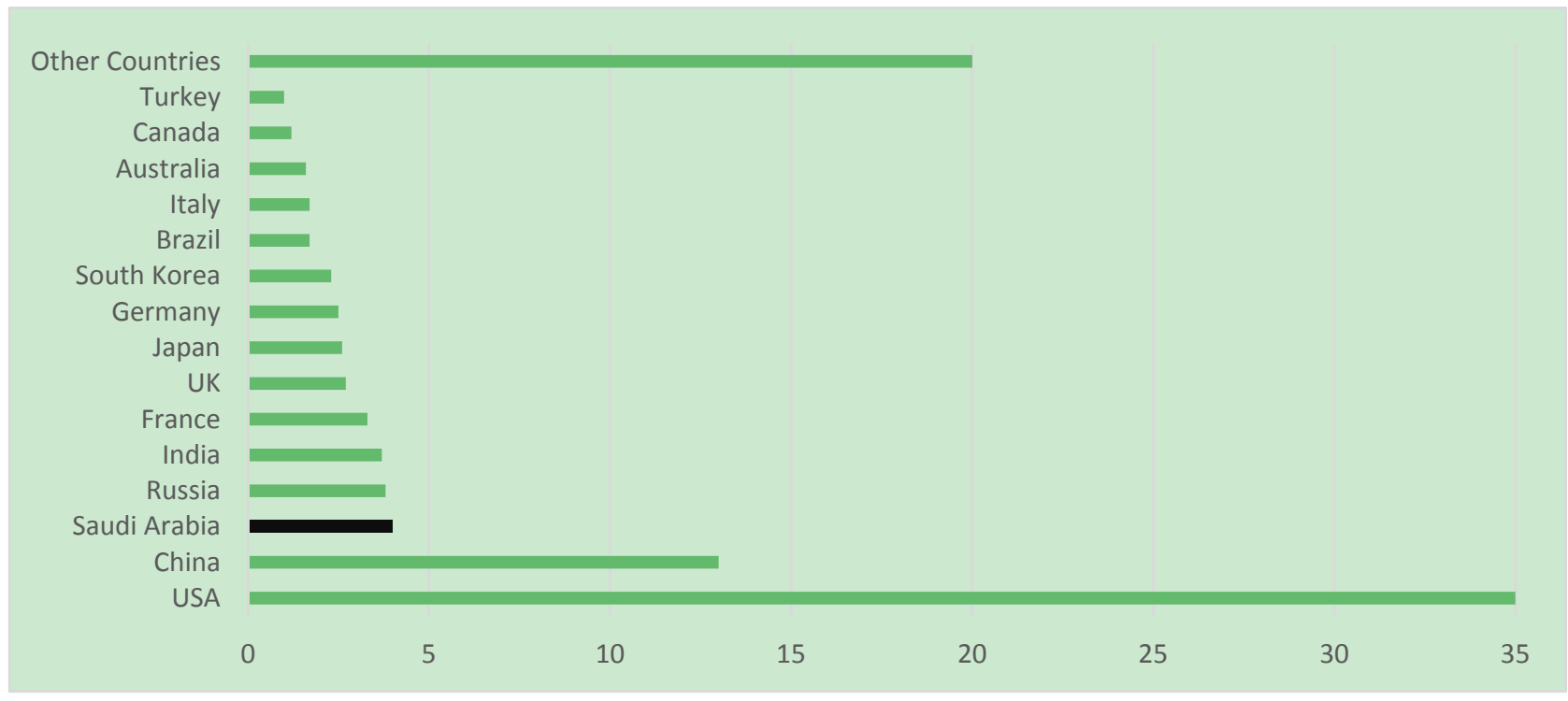

Graph 3. The share of world military expenditure of 15 states with the highest spending

Source: SIPRI (2018). Military Expenditure Database (2 May 2018): Military Spending Graphics of 2017. Stockholm International Peace Research Institute.

Similarly, Qatar has established a new Turkish military base in the country and radically increased its arms purchases in response (Aras \& Akpinar, 2017). According to Britain's Department for International Trade, Qatar has moved since 2015 from the world's sixth largest to the third-largest buyer of military equipment (Dorsey, 2017).

The consequences of this political crisis and associated arms race extend to the social policymaking sphere. As a result, GCC defence budgets have risen as a percentage of GDP. They more significantly are also rising as a share of government spending (Vickers, 2018). 
Although the countries involved in the dispute face the same challenge, different policy responses have taken place to increase governmental revenues. By exploring these responses, the following section will capture relevant social inclusion/exclusion patterns.

\section{Social Inclusion and Exclusion in Policy Response}

After exploring the structural and contemporary challenges facing the GCC countries in policymaking, this section focuses on examining the social inclusion/exclusion trends within policy transformations that ensued. The analysis attempts not only to map the social inclusion/exclusion trends but also to explore the driving forces behind such patterns.

In general, the analysis of social inclusion/exclusion in policy shifts are complex due to the difficulty of understanding the multi-layered construction of power relations, shaping social inclusion/exclusion trends within transforming policies (Miller et al., 2006). The GCC countries, in particular, provide a unique case of this complexity, as the six countries have been witnessing rapid policy transformations since the 2014 oil crisis. Just one example of a recent policy development, which incorporated social exclusion in Kuwait, is the approval of the parliament in early 2018 of a proposal by a Member of Parliament (MP) to oblige contractors (sponsors) to deport expatriate workers once their projects are completed (Ibrahim, 2018). Moreover, in late 2018, while the Kuwaiti parliament was discussing a new taxation law on expats, the same MP stated that "Expatriates must be charged for everything, for medical services, infrastructure, and again I say for the air they breathe here" (Gulf Business, 2018).

Looking at the GCC as a whole would have been more inclusive - but would require a bigger research project. Accordingly, for comparative reasons, the two widely differing cases of Saudi Arabia and Qatar are presented as examples of GCC inclusion and exclusion trends.

\subsection{The Case of Saudi Arabia}

\subsubsection{Context of Change: A new Crown Prince and the Obituary of Deep-rooted Legitimacy}

To better explore the social exclusion trends in the recent labour policy transformations in Saudi Arabia, a clear understanding of the contextual root causes is required.

Since the formulation of Saudi Arabia as a modern state in 1932 and till this moment, there has been no constitution or supreme law in the country that establishes precedent. The kingdom's legitimacy instead is built on the following two interconnected pillars:

\section{A. Tribalism}

In general, tribalism in the Gulf states is a central principle of authority. Tribalism in Saudi Arabia in specific is a fundamentally a notion of supremacy to the extent that the country itself is named based on the ruling tribe, which is Al- Sa ud. Historically, Al-Sa ud has been the driving force behind three state formations on the Arabian Peninsula - the first Saudi dynasty (1745-1811); the second Saudi dynasty (1843-65); and the modern kingdom of Saudi Arabia (1932-), founded by Abd-Alaziz ibn Abd-Arahman Al-Sa'ud (hereafter Ibn Sa ud) (Stenslie, 2012). In 1932, Ibn Sa ud expanded the tribal authority over the territory of Hijaz, Najd, Asir, and Hasa after a long campaign of conquest, and announced the formulation of the Kingdom of Saudi Arabia (Al-Rasheed, 2010). Since the formulation of the kingdom, tribalism has been the cornerstone of domestic power. According to Al-Rasheed (2010), tribal authority is one of the few continuities in Saudi's social and political history.

\section{B. Wahhabism}

The religious appearance of Saudi Arabia is unique due to its possession of the holiest Islamic sites, which are symbolically relevant to the Muslim world. However, possessing holy sites is not enough to build state legitimacy in a complex context in Saudi Arabia. The power cube theory provides insight to frame the alliance between religious class and the tribal authority as interrelated sources of power with the Kingdom (Gaventa, 2006). The kingdom has historically relied on religious legitimacy since the establishment of the first Saudi state in 1745. Ibn Sa ud established a strong alliance with Muhammad ibn Abdul Wahab, who led a movement for religious reform. Based on his name, 'Wahhabism' is considered to be a reform project of a moral nature that has sought to liberate Islam from accumulated false habits, heresies, and misguided superstitions, and to return to the purity of the faith that the righteous predecessors had. The alliance with ibn Abdul Wahhab in the first Saudi state has developed into an alliance with Muhammad al-Sheikh in the modern kingdom of Saudi Arabia as a continuation of Wahhabism (Samin, 2015).

In general, the use of tribal authority in the Gulf states is combined with an Islamic outlook (Partrick, 2013). The kingdom of Saudi Arabia is a clear example of this interlinkage. The alliance between tribalism and Wahhabism has been reproduced since the establishment of Saudi Arabia as interconnected sources of legitimacy. Stenslie 
(2012) described this alliance as an 'elite integration' between the royal family and sub elites including a religious class and businessmen, which is a successful mechanism of Al-Sa ud continuity.

However, this profound and historical tribe-religion axis of state legitimacy has been drastically undermined by the new leadership in Saudi Arabia. On June 20, 2017, Saudi Arabia's King Salman bin Abdulaziz appointed his son Mohammed bin Salman as crown prince - replacing his nephew, Mohammed bin Nayef, as first in line to the throne. Before he was appointed crown prince, he was in charge of leading Saudi Arabia's war in Yemen and overseeing the kingdom's energy policy and economic reform (BBC, 2017). The 32-year-old crown prince Mohammed bin Salman is now considered the de facto ruler of Saudi Arabia (Shukri, 2018). He essentially rules the kingdom as a replacement for his ailing 82-year-old father (Vick, 2018).

As the real power behind the throne, Saudi Arabia has experienced a period of rapid transformations since his appointment (Mabon, 2018). The literature varies in its analysis of this change, looking at the positive and negative sides. The positive sides include transforming the society to a more socially progressive one including the establishment of the General Authority for Entertainment - followed by aggressive entertainment events and festivals, granting driving licenses to women and opening cinemas, etc. (Al-Ghalib et al., 2018; Chara, 2018; Janbi, 2018). However, numerous critiques have emphasised that the new crown prince is rapidly undermining the strong inveterate tribe-religion axis of the kingdom's power and legitimacy. Five months after his appointment, bin Salman imprisoned 11 of the kingdom's most powerful princes, around 40 former ministers, and several people in business, who were arrested at the Ritz-Carlton hotel in Riyadh and accused with corruption (Stenslie, 2018). However, it is worth noting that there was no formal legal process and no transparency regarding these arrests (Vick, 2018).

These major changes could be understood in the theoretical framework of the non-incremental model in policymaking, as they have not been built on logical, incremental rationale (Rajagopalan \& Rasheed, 1995). Arresting princes from the royal family set a radical precedent that undermines the deep-rooted notion of tribalism.

Not only was exclusion exercised against royal family members, but religious figures have also been subject to the new crown prince's exclusion policies. Such radical transformations include the imprisonment of royal princes as well as well-known Wahhabi religious figures, in addition to the Kingdom's move to limit the authority of its historically most powerful religious entity, "The Committee for the Promotion of Virtue and the Prevention of Vice".

Many scholars have considered the new policies as a symbol of 'shaking up the system' (Gause III, 2018), a revolution, or an 'obituary' proclaiming an end to the interrelationship of religion, tribalism, and power in Saudi Arabia (Cowan, 2018). The extension of such claims has even forayed into the territory of identifying these controversial decisions as a harbinger of the 'end of elite unity and the stability of Saudi Arabia' (Stenslie, 2018).

\subsubsection{Reflection on Labour Policies}

In this context of overall exclusion in policy transformations in the Kingdom, labour policies are no exception. Since the appointment of the new crown prince, the Saudi government introduced numerous radical changes in labour policies under two banners: first, Saudi nationalisation (hereafter "Saudization") - in other words called "Nitaqat", which means larger domestic labour market restructuring, and where the government requires employers to fill their workforce with specific levels of Saudi nationals (Alabdulkarim, 2018). Saudization is not a new policy trend. However, the aggressive implementation is a tangible new transformation, however - as explained later in this section. Second, the long-term socioeconomic reform disposition, represented by Saudi's "Vision 2030" which is the primary roadmap for the Kingdom's economic and social policies, including diversifications of government sources of revenue (Nakhle, 2016). The vision has been followed by associated implementation programs, such as the "Fiscal Balance Program 2017 - 2022" and the "Transformation Program 2020" (Mitchell \& Alfuraih, 2018).

Despite the official banners used to justify the transformations in labour policies, these facilitate the structural social exclusion of expats in Saudi Arabia. The following policies are concrete illustrations of social exclusion embedded within the transformation of labour policies:

\section{A. Introduction of Taxation on Expats' Families}

Effective from July 1, 2017, the Saudi government implemented the newly introduced taxation system on expatriates' dependents. According to the new system, all expats in Saudi Arabia who are sponsoring dependents will have to pay a monthly tax of Saudi Riyal (SAR) 100 per dependent (approximately USD 27). This monthly tax will gradually increase over four years until it reaches SAR 400 (approximately USD 106) in 2020. The dependent tax is payable for spouses, dependent children, parents, and domestic workers (Ernst \& Young, 2017). 


\section{B. Introduction of Taxation on Private Sector for Expat Hiring}

As part of the Saudization plan, the government forced companies employing more foreign nationals than Saudi nationals to pay a monthly fee of SAR 400 (approximately USD 106) per foreign national employee or SAR 300 (approximately USD 80) if they employ more Saudi nationals starting in 2018. These fees are to be doubled each year until it reaches SAR 800 (approximately USD 213) per foreign national employee if companies employ more foreign nationals than Saudi nationals or SAR 700 (approximately USD 187) if they employ more Saudi nationals (PwC Middle East, 2017).

\section{Massive Deportation of Expats}

In addition to imposing a new taxation system on expats, the official data refers to a massive deportation policy, and the Saudi government adopted against expats over the last couple of years. As explained earlier in this section, Saudization is not a new trend; however, its radical implementation in the past two years is indeed. A Saudization campaign entitled "A Nation without Violators" was launched on March 2017, resulting in the deportation of 758,570 expats from 140 nationalities. In August 2018, an additional 1.6 million expats were arrested, mostly under charges related to residency $(1,238,046)$, and labour laws $(263,205)$, while 123,767 mostly Yemenis were deported and accused of illegal border crossing (Bel-Air, 2018). These mass deportations have been criticised from international organisations concerned with human rights like Amnesty International, which reported that the deported expats had been packed into severely overcrowded makeshift detention facilities where they received little food and water and were abused by guards (Global Detention Project, 2017).

\section{Saudization of specific retail sectors}

The Saudi Ministry of Labour and Social Development put in place three phases of Saudization for 12 retail sectors to replace expats workers by Saudi nationals. According to the Ministry's directives. The first phase was effective in September 11, 2018, where Saudization is to take place in car and motorbike showrooms, shops selling readymade garments for men and children, home and office furniture shops, and shops selling kitchenware. The second phase of Saudization started on November 9, 2018, covering electrical and electronics shops, watch shops, and optical stores. The third phase was effective on January 7, 2019, covering jobs in building and construction goods stores, medical appliances, and equipment shops, car spare parts shops, shops selling carpets, confectionary shops and patisseries (Saudigazette, 2019). The Ministry deployed inspectors in all regions of the Kingdom to follow up on the implementation of its decision by investigating these shops and taking punitive measures against the violators. After the implementation of the first two phases, the Ministry guidelines for the Saudization mechanism targeting the activities mentioned above have been scaled down from $100 \%$ to $70 \%$ Saudization (Al Bawaba, 2018).

Although these rapid transformations in labour policies in Saudi Arabia have been examined through various perspectives, yet, the social inclusion/exclusion issue in this regard represents a research gap and needs further evidence. A body of literature emerged, trying to assess the effectiveness of these policies from different perspectives. Such literature has examined the productivity and the private sector survival in Saudi Arabia, where it relies heavily on foreign labour, comprising of around 90\% of its employment (Alabdulkarim, 2018). Other literature describes the acceleration in protection schemes for national employment as a 'jobs crisis' where questions related to the experimental nature of Saudization has been raised (Young, 2018). Young (2018) questions why certain sectors are targeted and how smaller businesses will be able to assume the higher wage costs of hiring nationals, even if foreigners are less welcome in the Kingdom. Other literature looks at the cultural aspects and whether Saudi nationals accept/can work in certain fields taking into account that neither the education system nor the prevailing culture emphasises the development of soft skills, which represents a constraint to implementing Saudization in certain fields (Azhar et al., 2018).

Regardless of the official justifications announced by the government in terms of economic reform or increasing the employment rate among Saudi nationals, social exclusion of expats has been structurally embedded throughout the reorganisation of its labour force and other policy transformations. In addition to forced deportation, there has been a voluntary return of expats who decided to leave Saudi Arabia on their own free will (World Bank, 2017). Impacted by the imposed taxation system, expats in record numbers left the Kingdom, either voluntarily or by being a subject of the company layoffs to avoid paying higher fees (Omran, 2018). This taxation system exclusively targeting expats has left direct consequences on maternity, child wellbeing, family stability, and cohesion, as many family members of expat workers leaving the Kingdom to avoid these taxes are mainly those of breadwinner fathers of low incomes. Government figures show that more than 300,000 expats lost their jobs in the first nine months of 2017 (France 24, 2018). According to the national labour market bulletin for 2018 quarter 3, issued by the Saudi General Authority for Statistics on January 27, 2019, 839,000 expats left the Saudi labour market in the 
nine months from January until September 2018 (CNN Arabic, 2019).

\subsection{The Case of Qatar}

\subsubsection{Context of Change: Labour Rights and the GCC Crisis}

Before mapping the new transformations in labour policies in Qatar, this section will provide an overview of the context of change in Qatar. If the non-incremental model driven by new leadership can explain why the change took place in Saudi Arabia towards more exclusion, in Qatar, the case is different.

The two sources of external influence below can be considered as contributing factors towards a response of more social inclusion in labour policies in Qatar. Theories of social inclusion assume that facing an emerging crisis at the national level might drive the policy response towards more social inclusion, driven by a need to satisfy expectations (Mascareño \& Carvajal, 2016; Peters \& Besley, 2014). This theoretical framework affords a reasonable explanation for the transformation in Qatar towards more social inclusion in labour policies.

\section{A. World Cup 2022 and the Elevation of Migrant Labour Rights}

Global sport is playing a critical role in Qatar's soft power and international strategy, most notably through the successful bid in 2010 to host the 2022 Football World Cup (Brannagan \& Giulianotti, 2015). In preparation, Qatar is planning to spend an estimated USD 100 billion on infrastructure projects, including a new airport, roads, hotels, and stadiums. These massive infrastructure projects have been subject to widespread condemnations of the abuse of migrant workers' rights voiced by international unions, the International Labour Organization (ILO), human rights organisations, and the media. This extensive criticism has provided an opportunity to push for a change in labour policies in Qatar (Business \& Human Rights Resource Center, 2019). These criticisms address issues related to exploitation of the workers' rights, and have been repeated within the discourse of international media and international organisations as shown in the following excerpts: 1) Bringing workers from the world's poorest countries, paying them a pittance to deliver the football dream of the world's wealthiest per capita state (Conn, 2018), 2) Large numbers of migrant construction workers recorded as injured or killed through incidents related to their work. Other migrant workers reported poor, unsanitary living conditions and being 'trapped' by their Kafeels with passports withheld or wages not forthcoming (Millward, 2017), 3) Accusations of modern slavery practices, including evidence that thousands of migrant workers faced exploitation and abuses such as not being paid for months and have had their salaries retained to stop them from running away. Some workers reported that their employers routinely confiscate passports and refuse to issue ID cards, in effect reducing them to the status of illegal aliens, among other exploitation accusations (Pattisson, 2013), 4) Sponsors being granted legal powers by which they can abuse migrant workers. For example, a worker may not change or quit his job or leave the country without the employer's permission. Also, an employer has the authority to cancel the residence visa of a worker who quits his or her job without permission. In doing so, such a worker immediately becomes an illegal resident in the country, often providing cause for deportation proceedings, which can include prison time (ter Haar, 2018).

\section{B. GCC Crisis and the Terrorism Accusation}

As indicated in the challenges section, Qatar recently faced the worst geopolitical crisis of its modern history beginning when three Gulf States (Saudi Arabia, United Arab Emirates, and Bahrain) and Egypt (hereafter the Quartet) announced a cut of diplomatic ties with Qatar on June 5, 2017 (Rossi, 2018). The Quartet announced their intention to confront Qatar because of its alleged support of terrorism throughout the Middle East (Falk, 2018). Saudi Arabia, UAE, and Bahrain ordered their citizens to leave Qatar, declaring a ban on all travel to and from Qatar, and instructing Qatari residents and visitors to leave their territories within 14 days. In addition, the three GCC countries closed all air, sea and land transportation links with Qatar. Egypt joined the three as a symbolic representation of political and military regional power. Egypt maintained a limited number of diplomats under the protection of the Embassy of Greece in Doha, perhaps owing to the administrative needs of a large number of Egyptian residents within Qatar. The Quartet named 59 individuals and 12 institutions alleged to have financed terrorist organisations and to have received support from Qatar.

On June 23, 2017, the Quartet further issued a 10-day ultimatum on Qatar to abide by a list of 13 demands, including closing down of Al Jazeera News Network, cutting diplomatic and commercial ties with Iran, shutting down the Turkish military base in Qatar and, ending any form of support and assistance to the Muslim Brotherhood. On July 5, 2017, the Quartet replaced this initial list of demands with six broader "principles" that still include the shutting down of the permanent Turkish military base in Qatar, and the closure of Al Jazeera and other Qatarbacked news outlets which the Quartet accuses of spreading extremist views and providing platforms for dissidents (OHCHR, 2017).

Qatar did not respond to the list of 'unrealistic' and 'not actionable' demands as they were described by Sheikh 
Mohamed bin Abdulrahman Al Thani, Qatar Minister of Foreign Affairs, (The Peninsula, 2017a). In contrast, Qatar defended its independence and sovereign rights and called for negotiations (Falk, 2018). Kuwait took the lead in mediation with the support of the United States; however, the crisis persists with deeper implications and complicated dimensions on all actors (Kristian C. Ulrichsen, 2018).

The crisis is complicated due to its debatable dimensions. There has been a body of literature addressing numerous socioeconomic, regional security, international law and political consequences of the crisis as indicated in the challenges section. However, what is essential for this contextual analysis is how the crisis has contributed to more social inclusion in policy response.

The crisis prompted an immediate national reaction of solidarity among the population at large, nationals - who represent 10.1 percent of the population, and expats - who account for 89.9 percent of the population (EUI Migration Policy Center \& Gulf Research Center, 2016). These cohesive movements, campaigns, initiatives, and the widespread supportive hashtags are described in the literature as 'the wave of popular nationalism', most notably, Tamim Al Majd (Oruc, 2018), which illustrates that nationalism is not exclusively for nationals in some of the GCC contexts (Koch, 2016). This was reflected in the clear key messages of social inclusion signalled through the political discourse of Qatar's ruling family. As an example, during the $72^{\text {nd }}$ Session of the United Nations General Assembly, the Emir of Qatar Sheikh Tamim bin Hamad Al-Thani stated: "Allow me, on this occasion and from this podium, to express my pride in my Qatari people, along with the multinational and multicultural residents in Qatar"(The Peninsula, 2017b).

\subsubsection{Reflection on Labour Policies}

Considering the theoretical framework of social inclusion that assumes facing an emerging crisis might drive the policy response towards more social inclusion the international pressure related to the labour rights and the 2017 GCC crisis played a major role in energising the labour policy transformations.

As reported by many international organisations and the literature, Qatar has significantly revised its legal framework in several areas that are relevant to the issue of migration. The revision has led to the establishment of rules and regulations that better conform to international standards in areas of labour rights (Zahra, 2018). Below are the major transformations of labour policies in Qatar.

\subsubsection{Explicit Labour Policy Development}

\section{A. Abolishment of the Kafala System}

Since 2015, Qatar has started gradually to abandon the discriminating legal conditions of expat workers. The starting point was the issuance of "law no. (21) of 2015 regulating the entry and exit of expatriates and their residence" ( State of Qatar, 2015), which replaced the Kafala system in 2004 Labour law, and replaced the "law No. (4) of 2009 regulating the entry and exit of expatriates and their residence and sponsorship"( State of Qatar, 2009). The new law of 2015 did not mention the Kafala system. It replaced it with a new contractual relationship between the expatriate worker and the recruiter, not the sponsor (Kafeel - in the old system).

In a rapid development towards expatriate labour rights, law no. (1) of 2017 was issued to amend specific provisions of Law no. (21) of 2015, followed by further development by the issuance of Law no. (13) of 2018 (ILO, 2019). According to these laws, below are the major shifts in expatriate labour rights:

\section{B. Exit Permit Facilitation}

According to section (7) in the 2015 law, an "expatriate worker or recruiter shall notify the competent authority of any departure from the country at least three days prior to the exit date". This step was to replace the formal exit permission that the Kafeel had to grant the worker in the former system through a 3-day notification.

This provision has been developed further by the 2017 and the 2018 laws, which made it possible for the expatriate worker to leave the country temporarily or permanently during the period of the labour contract. The 2018 law minimised the exit permission to a 5 percent only of the recruiter's employees, stating in section (1) of the law that "An expatriate worker, shall have the right to leave the country temporarily or to depart definitively from the country during the validity of the labour contract. The recruiter may submit a justified application to the Ministry of Labour, which includes the names of workers who must receive its prior approval, before their departure from the country due to the nature of their work. These workers must not exceed 5 per cent of the recruiter's employees."

\section{Introduction of the Appeal System}

Avoiding inflexibility on the part of a recruiter, who might object the worker's departure, the new legal system allows: "the expatriate worker... the right to appeal to an appeals committee in charge of the exit of expatriates. The committee shall decide on the exit request within three working days". 


\section{Minimising the Restrictions on Job Transfer Rights}

According to the former 2009 law, an expat could not move to another job unless there was a written contract between the current and the new Kafeels, which made it almost impossible for an expatriate worker to transfer between jobs. Section (21) in the 2015 law amended this by stating that "an expatriate worker may transfer to another employer before the end of the labour contract, upon approval of the employer, the competent authority and the Ministry of Labour. Upon approval of the competent authority and the Ministry of Labour, an expatriate worker may transfer to another employer immediately after the end of labour contract". The 2015 law also protected the expatriate worker from the recruiter's intransigence if there are ongoing legal trials between them. Section (22) stipulates that: "The Ministry shall accept the temporary transfer of an expatriate worker to another employer if there are pending lawsuits between the expatriate worker and his recruiter".

\section{E. New Legislation for Domestic Workers Protection}

The 2017 Labour Force Survey reported that Qatar had 172,000 domestic workers (Planning and Statistics Authority, 2018). On August 22, 2017, Qatar issued the "law no. (15) of 2017 concerning Domestic Workers" (State of Qatar, 2017). Qatar's adoption of a new law on domestic workers provides labor rights for domestic workers for the first time. In contrast, before this law, they were excluded from legal protection provisions (Human Rights Watch, 2017).

Section (7) and (8) of the law addressed much international criticism related to slavery treatment of domestic workers. Section (8) also regulated the payment conditions to ensure no exploitation from the employer. It states that "An employer shall be responsible for paying the monthly wage in Qatari Riyals agreed upon with the domestic worker at the end of the month, or the latest on the third day of the consecutive month. An employer shall not be considered as having met his/her duties unless he/she proves that he/she had deposited the worker's wage in his/her bank account, or handed him /her the wage in cash, by a receipt signed by the worker, which confirms his/her receipt of the wage in full. An employer shall be prohibited from deducting any fees, expenses or commissions from a worker's wage in return for the procedures of recruitment from abroad."

\subsubsection{Implicit Inclusion Policy Developments}

In addition to the above-mentioned explicit transformations in labour policies, other inclusion amendments have taken place recently in Qatar as follows:

\section{A. New Legislation to grant Permanent Residency to Expatriates and Excluded Groups}

On September 4, 2018, Qatar issued law no. (10) of 2018 on permanent residency, by which the expatriates are allowed to obtain a permanent residency permit of Qatar under specific rules and regulations (The Peninsula, 2018). According to the new law, expats who were born in Qatar and completed ten years' residence, or who were born abroad and completed 20 years in Qatar on a legal ordinary residency permit, are eligible to apply for a permanent residency. The new permanent residency will not shift these groups to a citizenship level; however, they will benefit from secured residency, education and health coverage for citizens.

The law also extended permanent residency to certain groups, such as children of Qatari women married to nonQataris, non-Qatari husbands of Qatari women, expatriate wives of Qatari citizens, and children of Qataris with naturalisation.

\section{B. A New Legislation to allow One Hundred Percent Investment by Non-Qataris}

In January 2019, Qatar issued law no. (1) of 2019 regulating the investment of the non-Qatari capital in economic activity. The law opens the way for foreign investors to have 100 percent ownership in all sectors, as well as support for investors' entry into the Qatari market. The new law offers many investment incentives, including an allocation of land to non-Qatari investors to establish investment through the use or rent following the applicable rules and regulations. (The Peninsula, 2019a).

The new provision provides inclusion space for non-Qatari investors. They had previously been allowed to invest a maximum of 49 percent in the equity of Qatari Limited Liability Companies according to the law no. (13) of 2000 (Ernst \& Young, 2018). The 49 percent kept the control or dominance of the investment with a Qatari partner who owns the remaining 51 percent of the investment. According to the 2019 new law, the non-Qatari investors not only benefit from 100 percent investment ownership, but they can also import machinery and necessary equipment with exemption from customs.

\section{New Legislation to allow Non-Qatari Property Ownership}

The Qatari Cabinet of Ministers approved a draft resolution on March 13, 2019, determining the areas and places in which non-Qataris are allowed to own and use real estate, which was previously an exclusive right for nations. 
According to the resolution, the ownership of real estate would grant a residence to the Non-Qatari owner. The resolution comes in implementation of law no. (16) of 2018 on the regulation of Non-Qatari ownership and use of real estate (The Peninsula, 2019b).

\section{Introduction of a Free-visa to Eighty Nationalities}

On August 8, 2017, Qatar's Ministry of Interior, Tourism Authority and Qatar Airways announced a new visa policy, allowing citizens of 80 countries visa-free entry. With this announcement, Qatar ranks the highest in the region in terms of the number of nationalities eligible to enter visa-free. The political discourse in Qatar marked this development as an outstanding improvement for opening the country in times of the recent GCC crisis. During the announcement press conference, Qatar Airways Group Chief Executive commented "This historic announcement comes at a time of historical significance. While some countries in the region have taken to closing their skies and their borders, Qatar has instead opened its borders to more freely welcoming visitors from all corners of the world" (Rivera, 2017).

In general, Qatar has been adopting a rapid transformation tendency in policies related explicitly or implicitly to labour, migration, and demographic imbalance in the country. These transformations among others are part of a big picture of Qatar as a 'transformative state', signalling the state's modernity to the world and proofing the capacity to design and implement a comprehensive, rapid transition to an advanced state and society (Tok et al., 2016). The social inclusion trend has been clear as mapped throughout the abovementioned frequent policy shifts. As explained, these developments have been praised by many international entities, including the ILO and Human Rights Watch. However, some critique is still valid related to the minimum wage required as a prerequisite to apply for a family member residency, which limits the rights of low-income workers for family reunification. However, they can still bring their family members on a visit visa for up to 6 months. It is also worth mentioning that despite the inclusive development of permanent residency legislation, yet it did not appease the demands of children of Qatari mothers from foreign fathers who had previously requested citizenship, who are still excluded from citizenship. In brief, the explicit and implicit labour policy transformations are embedding social inclusion, and gradually more improvements need to occur.

\section{Conclusion}

The formulation process of social policies in general and labour policies in particular, is complicated in the Gulf context. This is due to the abiding structural challenges in addition to the contemporary ones, which border the state's margin of policy change. The abiding challenges include the rentier state model, which has been built on the concept of redistribution of hydrocarbon revenue. Since mid-2014, the volatility of global oil prices has put the sustainability of this model under critical examination. Governmental policy responses consider the cradle-tograve granted privileges for nationals, which exacerbate the economic burden on the state, as well as contribute to a structural social exclusion of expatriates, who are usually eliminated from such provisions. In addition to the socioeconomic burden, the labour market structure is another abiding policy constraint, as it is heavily dependent on the expatriates, resulting in an extreme demographic imbalance, which reaches to as low as 10.1 percent of nationals from the total population in Qatar and 11.5 percent in the United Arab Emirates. Recent political and security challenges have also intensified the social policymaking constraints in the GCC. The unfinished war in Yemen, along with the recent Gulf crisis, has contributed to a drastic increase in the arms race throughout the Gulf.

After providing an overview on the macro level challenges, the transformations that have happened recently in labour policies in the Gulf have been mapped with a focus on capturing the social inclusion/exclusion trends in these policy transformations. A comparative perspective has been drawn between Qatar and Saudi Arabia, to explore the dilemma that regardless of similar macro-level challenges, an inclusion trend was clear in the development of labour policies in Qatar. At the same time, the exclusion was the case in Saudi Arabia. It is evident through the improvement of labour policies in Qatar including the abolishment of the Kafala system, the issuance of the domestic workers' law, the introduction of new regulations that grant permanent residency to expatriates, among other major explicit and implicit developments detailed throughout the analysis. In contrast, the evidence of social exclusion in Saudi Arabia has been constructed by certain transformations such as the introduction of a new taxation system on expatriates' families, a new taxation system on the private sector for hiring expatriates and massive deportation, among other policies.

The comparison between Qatar and Saudi Arabia was explored within the different demographic setup and labour structure in both countries. As indicated in the challenges section, unlike Qatar, where expatriates represent 89.9 percent of the total population, Saudi Arabia is less dependent in terms of the labour structure on expatriates, where they represent 32.7 percent of the total population. Considering the high unemployment rates among nationals in Saudi Arabia, exclusion policies could be justified from the state perspective based on an underlying principle and 
legitimate goal of protecting and empowering nationals. However, a justification from a social justice perspective is hard to be attained.

As stated throughout the analysis, the political ecology of social justice and social stratification system is complex in the Gulf context. Accordingly, it is worth noting that the highlighted findings related to the social inclusion trend in Qatar and exclusion in Saudi Arabia are based on the major frequent tendencies in policy transformations in both countries. This finding does not mean that there is no exclusion in Qatar and no inclusion in Saudi Arabia. For example, despite the significant developments in Qatar's labour policies, yet there is criticism related to the minimum wage as a prerequisite for an expatriate worker to bring a family member, restricting the right for a family reunion, among other criticisms related to the effective implementation of the new legislations.

The analysis also outlined how similar challenges in the GCC context has led to different policy responses in terms of the root causes that led Qatar towards inclusion and Saudi Arabia towards exclusion. Although the macro level challenges remain the same across the GCC countries, each country has its unique context. The context of change in Saudi Arabia was explored within a storm of policy changes. These changes imbedded exclusion trends at different levels, not only against expatriates but also against royal family members and religious figures, which could lead to destabilisation of the society and undermining of the profound legitimacy. Meanwhile, in Qatar, the labour policy changes have taken place gradually over the past five years within the context of growing international criticism of the labour rights after winning the world cup bid of 2022. In addition, the recent GCC crisis against Qatar and the allegations of supporting terrorism have accelerated the development of labour policies towards social inclusion in a context of significant policy transformations at the state level to counter the accusations and prove the openness and the modern outlook of the country.

The article represents a foundation for future research to generate evidence on an in-depth understanding of social inclusion and exclusion in the GCC. The ideal pathway is to conduct a research project employing a mixed-method of qualitative and quantitative tools to assess the impact of these policy transformations on the expatriates' livelihood, experiences and to explore to what extent these shifts contributed to social inclusion and exclusion among expatriates themselves.

\section{References}

Al Bawaba. (2018, August 29). 70 Percent Saudization in These 12 Sectors. Al Bawaba. Retrieved from https://www.albawaba.com/business/70-percent-saudization-these-12-sectors-1178800

Alabdulkarim, M. (2018). Labour Demand, Firm Survival \& Productivity in Dual Labour Markets: The Case of the Nitaqat Policy in Saudi Arabia [PhD Thesis]. King's College London.

Alaraby. (2018, September 7). Saudi Arabia, UAE to shoot up GCC military spending growth. Alaraby. Retrieved from https://www.alaraby.co.uk/english/news/2018/9/7/saudi-arabia-uae-to-shoot-up-gcc-military-spending

Alasfoor, R. (2007). The Gulf Cooperation Council: Its nature and achievements. Department of Political Science, Lund University.

Al-Ghalib, S. J., Salim, A. Y., Al-Khalifah, S., \& Dahlawi, R. A. (2018). Perceptions of Women's Driving in Saudi Arabia: Relationship with Openness to Experience and Happiness. Middle East Journal of Positive Psychology, 4(1), 102-125.

Al-Rasheed, M. (2010). A history of Saudi Arabia. Cambridge University Press. https://doi.org/10.1017/CBO9780511993510

Aras, B., \& Akpınar, P. (2017). Turkish Foreign Policy and the Qatar Crisis. IPC Policy Brief Istanbul: Istanbul Policy Center.

Aref, A. (2018). Contribution of Social Policies in Achieving Work-Family Balance. Third International Women and Justice Summit on Family Empowerment.

Azhar, A., Duncan, P., \& Edgar, D. (2018). The Implementation of Saudization in the Hotel Industry. Journal of Human Resources in Hospitality \& Tourism, 17(2), 222-246. https://doi.org/10.1080/15332845.2017.1406271

Azzam, Z., \& Harb, I. (2018). The GCC Crisis at One Year: Stalemate Becomes New Reality. Arab Center Washington DC.

Babar, Z. (2015). Population, Power, and Distributional Politics in Qatar. Journal of Arabian Studies, 5(2), 138155. https://doi.org/10.1080/21534764.2015.1113680

Babar, Z., \& Gardner, A. (2016). Circular Migration and the Gulf States. In Impact of Circular Migration on 
Human, Political and Civil Rights: A Global Perspective. Springer. https://doi.org/10.1007/978-3-319-288963_3

Bandirali, A. (2018). Expatriates' Labor Within the Gulf Cooperation Council Framework: Steps Forward in Ending Abuses? [Università Ca' Foscari Venezia]. Retrieved from http://dspace.unive.it/bitstream/handle/10579/13220/861614-1218019.pdf?sequence=2

BBC. (2017, June 21). Saudi king ousts nephew for son. BBC. Retrieved from https://www.bbc.com/news/worldmiddle-east-40351578

Bel-Air, F. D. (2018). Demography, Migration and Labour Market in Saudi Arabia (No. 5/2018). Gulf Labour Markets and Migration GLMM. Retrieved from http://gulfmigration.org/media/pubs/exno/GLMM_EN_2018_05.pdf

Bellin, E. (2012). Reconsidering the robustness of authoritarianism in the Middle East: Lessons from the Arab Spring. Comparative Politics, 44(2), 127-149. https://doi.org/10.5129/001041512798838021

Berger, L. (2014). The Gulf Cooperation Council between Unity and Discord towards the Arab Uprisings. Sicherheit Und Frieden (S+ F)/Security and Peace, 260-264. https://doi.org/10.5771/0175-274x-2014-4-260

Brannagan, P. M., \& Giulianotti, R. (2015). Soft power and soft disempowerment: Qatar, global sport and football's 2022 World Cup finals. Leisure Studies, 34(6), 703-719. https://doi.org/10.1080/02614367.2014.964291

Business \& Human Rights Resource Center. (2019). Labour rights and the Qatar World Cup 2022. Business \& Human Rights Resource Center. Retrieved from https://www.business-humanrights.org/en/major-sportingevents/labour-rights-and-the-qatar-world-cup-2022

Callen, M. T., Cherif, R., Hasanov, F., Hegazy, M. A., \& Khandelwal, P. (2014). Economic diversification in the GCC: Past, present, and future. International Monetary Fund. https://doi.org/10.5089/9781498303231.006

Chara, J. (2018). Saudi Arabia: A prince's revolution. European View, 17(2), 227-234. https://doi.org/10.1177/1781685818803525

Clegg, S. (2005). Evidence-based practice in educational research: A critical realist critique of systematic review. British Journal of Sociology of Education, 26(3), 415-428. https://doi.org/10.1080/01425690500128932

CNN Arabic. (2019). 839,000 Expats left Saudi Labour Market in 9-month from 2018. Retrieved from https://arabic.cnn.com/business/video/2019/01/27/v70919-bjan19-saudi-market-labor

Conn, D. (2018, November 21). Qatar 2022: $£ 40$ a week to build the World Cup stadiums. The Guardian. Retrieved from https://www.theguardian.com/football/2018/nov/21/qatar-2022-40-a-week-to-build-the-world-cupstadiums

Cowan, D. (2018). Revolution or Obituary? In The Coming Economic Implosion of Saudi Arabia (pp. 23-51). Springer. https://doi.org/10.1007/978-3-319-74709-5_2

Dagher, A. (2014). Unconventional Control: Impacts of Unconventional Oil and Gas in the GCC. Luciani, G. and Ferroukhi, "The Political Economy of Foreign Reform: The Clean Energy-Fossil Balance in the Gulf States". Gerlach Press, Germany, 59-83. https://doi.org/10.2307/j.ctt1df4hfz.6

Davis, J. (2016). The Arab Spring and Arab Thaw: Unfinished Revolutions and the Quest for Democracy. Routledge. https://doi.org/10.4324/9781315612485

Diop, A., Li, Y., Al-Ansari, M. M. H. A., \& Le, K. T. (2017). Social Capital and Citizens' Attitudes towards Migrant Workers. Social Inclusion, 5(1), 66. https://doi.org/10.17645/si.v5i1.798

Dorsey, J. (2017, August 17). The Two Faces of the Gulf Crisis: Arms Race. The Globalist. Retrieved from https://www.theglobalist.com/gulf-crisis-qatar-saudi-arabia-uae-arms/

ElGindi, T. (2016). Oil and Natural Gas in GCC Countries. Academic Foresights. https://doi.org/10.5339/qproc.2016.qgbc.7

Ernst, \& Young. (2016). The Impact of Decreasing Oil Prices on the GCC RHC Market. Ernst \& Young Global Limited EYGM. Retrieved from https:/www.yumpu.com/en/document/read/56410196/the-impact-ofdecreasing-oil-prices-on-the-gcc-rhc-market/7

Ernst, \& Young. (2017). Mobility Tax Alert 2017: Saudi Arabia to introduce expatriate dependentlevy. Ernst \& Young Global Limited EYGM. from https://www.ey.com/Publication/vwLUAssets/Saudi_Arabia_to_introduce_expatriate_dependent_levy/\$FIL E/Saudi\%20Arabia\%20to\%20introduce\%20expatriate\%20dependent\%20levy.pdf 
Ernst, \& Young. (2018). Qatar announces draft law to allow 100\% foreign investment in all sectors (p. 3). Ernst \& Young Global Limited EYGM.

Errichiello, G. (2012). Foreign Workforce in the Arab Gulf States (1930-1950): Migration Patterns and Nationality Clause 1. International Migration Review, 46(2), 389-413. https://doi.org/10.1111/j.17477379.2012.00891.x

ESCWA. (2007). Literature Review on Social Exclusion in the ESCWA Region. United Nations Economic and Social Commission for Western Asia. Retrieved from https:/www.unescwa.org/publications/literaturereview-social-exclusion-escwa-region

EUI Migration Policy Center, \& Gulf Research Center. (2016). Gulf Labor Markets and Migration (GLMM) Demographic and Economic Database. Retrieved from http://gulfmigration.org/gcc-total-populationpercentage-nationals-foreign-nationals-gcc-countries-national-statistics-2010-2016-numbers/

Falk, R. (2018). A normative evaluation of the Gulf crisis. HSF Policy Brief, 1(1).

Fargues, P. (2011). Immigration without inclusion: Non-nationals in nation-building in the Gulf States. Asian and Pacific Migration Journal, 20(3-4), 273-292. https://doi.org/10.1177/011719681102000302

Fernandez, J. M. (2018). Special Report: The Qatar-Gulf crisis: The attack on media freedom and the West's loss of moral authority. Pacific Journalism Review: Te Koakoa, 24(2), 158-164. https://doi.org/10.24135/pjr.v24i1.401

France 24. (2018, March 27). Saudi Arabia imposes taxes on Families of Expats working in the Private Sector. France 24.

Gause, G. F., Gause III, F. G., \& Gause, F. G. (1994). Oil monarchies: Domestic and security challenges in the Arab Gulf states. Council on Foreign Relations.

Gause III, F. G. (2018). Fresh Prince: The Schemes and Dreams of Saudi Arabia's Next King. Foreign Aff., 97, 75.

Gaventa, J. (2006). Finding the spaces for change: A power analysis. IDS Bulletin, 37(6), 23-33. https://doi.org/10.1111/j.1759-5436.2006.tb00320.x

GCC-STAT. (2018). Population Statistics in GCC Countries 2010-2017. GCC Statistical Center. Retrieved from https://gccstat.org/en/statistic/statistics/population

Global Detention Project. (2017). Global Detention Project Submission to the UN Committee on the Elimination of Discrimination against Women-Saudi Arabia. CEDAW.

Gulf Business. (2018). Kuwait MP calls for foreign workers to be charged "for the air they breathe." Gulf Business . Retrieved from https://gulfbusiness.com/kuwait-mp-calls-foreign-workers-charged-air-breathe/

Hertog, S. (2014). Redesigning the distributional bargain in the GCC. In Gulf Politics and Economics in a Changing World (pp. 29-54). World Scientific. https://doi.org/10.1142/9789814566209_0003

Human Rights Watch. (2017, August 24). Qatar: New Law Gives Domestic Workers Labor Rights. Human Rights Watch. Retrieved from https://www.hrw.org/news/2017/08/24/qatar-new-law-gives-domestic-workers-laborrights

Ibrahim, A. (2018). Proposal of MP Safa Al-Hashim "Expat workers to be deported once their projects are completed" approved. Arab Times. Retrieved from http://www.arabtimesonline.com/news/proposal-of-mpsafa-al-hashim-expat-workers-to-be-deported-once-their-projects-are-completed-approved/

ILO. (2019). Database of national labour, social security and related human rights legislation. ILO Database of National Labour, Social Security and Related Human Rights Legislation. Retrieved from https://www.ilo.org/dyn/natlex/natlex4.detail?p_lang=en\&p_isn=102231

IMF. (2016). Economic Diversification in Oil-Exporting Arab Countries: Annual Meeting of Arab Ministers of Finance. International Monetary Fund. Retrieved https://www.imf.org/external/np/pp/eng/2016/042916.pdf

Janbi, W. A. (2018). Feminist Analysis: Saudi Arabian women seize their freedom through cinema [PhD Thesis]. Long Island University, The Brooklyn Center.

Kamrava, M. (2012). The Arab Spring and the Saudi-led counterrevolution. Orbis, 56(1), 96-104. https://doi.org/10.1016/j.orbis.2011.10.011

Koch, N. (2016). Is nationalism just for nationals? Civic nationalism for noncitizens and celebrating National Day 
in Qatar and the UAE. Political Geography, 54, 43-53. https://doi.org/10.1016/j.polgeo.2015.09.006

Labonte, R. (2004). Social inclusion/exclusion: Dancing the dialectic. Health Promotion International, 19(1), 115121. https://doi.org/10.1093/heapro/dah112

Lawrence, A., Houghton, J., Thomas, J., \& Weldon, P. (2012). Where is the evidence? Realising the value of grey literature for public policy and practice.

Mabon, S. (2018). It's a Family Affair: Religion, Geopolitics and the Rise of Mohammed bin Salman. Insight Turkey, 20(2), 51-66. https://doi.org/10.25253/99.2018202.04

Mascareño, A., \& Carvajal, F. (2016). The different faces of inclusion and exclusion. CEPAL Review, 2015(116), 127-141. https://doi.org/10.18356/00b3dff6-en

Miller, V., VeneKlasen, L., Reilly, M., \& Clark, C. (2006). Power: Concepts for revisioning power for justice, equality and peace. Washington, DC: Just Associates.

Millward, P. (2017). World Cup 2022 and Qatar's construction projects: Relational power in networks and relational responsibilities to migrant workers. Current Sociology, 65(5), 756-776. https://doi.org/10.1177/0011392116645382

Mishrif, A., \& Al-Naamani, S. (2018). Regional Integration, the Private Sector and Diversification in the GCC Countries. In Economic Diversification in the Gulf Region, Volume I (pp. 209-233). Springer. https://doi.org/10.1007/978-981-10-5783-0_10

Mitchell, B., \& Alfuraih, A. (2018). The Kingdom of Saudi Arabia: Achieving the Aspirations of the National Transformation Program 2020 and Saudi Vision 2030 Through Education. Journal of Education and Development, 2(3), 36. https://doi.org/10.20849/jed.v2i3.526

Modarres, A. (2010). Migration and the Persian Gulf: Demography, Identity and the Road to Equitable Policies. Anthropology of the Middle East, 5(1), 1-17. https://doi.org/10.3167/ame.2010.050102

Moher, D., Stewart, L., \& Shekelle, P. (2015). All in the family: Systematic reviews, rapid reviews, scoping reviews, realist reviews, and more. BioMed Central. https://doi.org/10.1186/s13643-015-0163-7

Naheem, M. A. (2017). The dramatic rift and crisis between Qatar and the Gulf Cooperation Council (GCC) of June 2017. International Journal of Disclosure and Governance, 14(4), 265-277. https://doi.org/10.1057/s41310-017-0025-8

Nakhle, C. (2016, June 24). Saudi Arabia's economic reform. Austrian Economics Center. Retrieved from https://www.gisreportsonline.com/saudi-arabias-economic-reform,economy, $1892 . \mathrm{html}$

Nusair, S. A. (2016). The effects of oil price shocks on the economies of the Gulf Co-operation Council countries: Nonlinear analysis. Energy Policy, 91, 256-267. https://doi.org/10.1016/j.enpol.2016.01.013

O’Campo, P., Molnar, A., Ng, E., Renahy, E., Mitchell, C., Shankardass, K., John, A. S., Bambra, C., \& Muntaner, C. (2015). Social welfare matters: A realist review of when, how, and why unemployment insurance impacts poverty and health. Social Science \& Medicine, 132, 88-94. https://doi.org/10.1016/j.socscimed.2015.03.025

OHCHR. (2017). OHCHR Technical Mission to the State of Qatar: Report On the impact of the Gulf Crisis on human rights. Office of the United Nations High Commissioner for Human Rights. Retrieved from http://nhrc-qa.org/wp-content/uploads/2018/01/OHCHR-TM-REPORT-ENGLISH.pdf

Omran, A. A. (2018, July 10). Record numbers of foreign workers leave Saudi Arabia. Financial Times. Retrieved from https://www.ft.com/content/c710cf30-8441-11e8-a29d-73e3d454535d

Oruc, N. (2018). Hashtag Unity in the Midst of the Blockade of Qatar [Master's Thesis]. Qatar University.

Øyen, E. (1997). The contradictory concepts of social exclusion and social inclusion.

Partrick, N. (2013). Nationalism in the Gulf states. In The Transformation of the Gulf (pp. 66-84). Routledge.

Pattisson, P. (2013). Revealed: Qatar's world cup 'slaves.' The Guardian, 25, 2013.

Pawson, R., Greenhalgh, T., Harvey, G., \& Walshe, K. (2005). Realist review-a new method of systematic review designed for complex policy interventions. Journal of Health Services Research \& Policy, 10(1_suppl), 2134. https://doi.org/10.1258/1355819054308530

Peters, M. A., \& Besley, T. A. C. (2014). Social Exclusion/Inclusion: Foucault's analytics of exclusion, the political ecology of social inclusion and the legitimation of inclusive education. Open Review of Educational Research, 1(1), 99-115. https://doi.org/10.1080/23265507.2014.972439 
Planning and Statistics Authority. (2018). Labor Force Sample Survey: Annual Report 2017. Planning and Statistics Authority.

Retrieved from https://www.mdps.gov.qa/en/statistics/Statistical\%20Releases/Social/LaborForce/2017/statistical_analysis_1 abor_force_2017_En.pdf

PwC Middle East. (2017). Saudi Arabia implements Expat levy (p. 2). PwC Middle East. Retrieved from https://www.pwc.com/m1/en/tax/documents/2017/expat-levy-update-july.pdf

Rajagopalan, N., \& Rasheed, A. M. (1995). Incremental Models of Policy Formulation and Non-incremental Changes: Critical Review and Synthesis 1. British Journal of Management, 6(4), 289-302. https://doi.org/10.1111/j.1467-8551.1995.tb00101.x

Rivera, R. (2017). Citizens of 80 countries can now enter Qatar visa-free. The Peninsula.

Rossi, C. (2018). Game of Thrones: The Qatar Crisis and Forced Expulsions on the Arabian Peninsula. Penn State Journal of Law \& International Affairs, 7(1).

Samin, N. (2015). Of Sand or Soil: Genealogy and Tribal Belonging in Saudi Arabia. Princeton University Press. https://doi.org/10.23943/princeton/9780691164441.001.0001

Saudigazette. (2019, January 6). Saudization in 5 key sectors from today. Saudigazette. Retrieved from http://www.saudigazette.com.sa/article/551779/SAUDI-ARABIA/Saudization-in-5-key-sectors-from-today

Shukri, S. F. (2018). Saudi Arabia in Transition: Insights on Social, Political, Economic and Religious Change. Edited by Bernard Haykel, Thomas Hegghammer and Stephane Lacroix. New York, USA: Cambridge University Press, 2015, pp. 351. Intellectual Discourse, 26(2), 949-951.

SIPRI. (2018). Military Expenditure Database (2 May 2018). Retrieved from https://www.sipri.org/research/armament-and-disarmament/arms-transfers-and-military-spending/militaryexpenditure

SIPRI. (2019). Global arms trade: USA increases dominance; arms flows to the Middle East surge. Stockholm International Peace Research Institute. Retrieved from https://www.sipri.org/media/pressrelease/2019/global-arms-trade-usa-increases-dominance-arms-flows-middle-east-surge-says-sipri

Spiess, A. (2010). Demographic transitions and imbalances in the GCC: Security risks, constraints and policy challenges. Conference Policy Paper Presented at The.

State of Qatar. (2009). Qatar - Law No. 4 of 2009 Regulating the Entry and Exit of Expatriates in Qatar and their Residence and Sponsorship. ILO Database of National Labour, Social Security and Related Human Rights Legislation. Retrieved from https://www.ilo.org/dyn/natlex/natlex4.detail?p_lang=en\&p_isn=102231

State of Qatar. (2015). Qatar - Law No. 21 of 2015 regulating the entry and exit of expatriates and their residence. ILO Database of National Labour, Social Security and Related Human Rights Legislation. Retrieved from https://www.ilo.org/dyn/natlex/natlex4.detail?p_lang=en\&p_isn=102231

State of Qatar. (2017). Qatar-Law No. 15 of 2017 concerning Domestic Workers. ILO Database of National Labour, Social Security and Related Human Rights Legislation. Retrieved from https://www.ilo.org/dyn/natlex/natlex4.detail?p_lang=en\&p_isn=105099\&p_count=8\&p_classification=22

Stenslie, S. (2012). Regime stability in Saudi Arabia: The challenge of succession. Routledge. https://doi.org/10.4324/9780203147801

Stenslie, S. (2018). The End of Elite Unity and the Stability of Saudi Arabia. The Washington Quarterly, 41(1), 61-82. https://doi.org/10.1080/0163660X.2018.1445360

Taylor, D. (2016). Critical policy evaluation and the question of values: A psychosocial approach. Critical Social Policy. https://doi.org/10.1177/0261018306059774

ter Haar, B. (2018). fifa, Qatar, Kafala: Can the World Cup Create a Better World of Work?: By Beryl ter Haar, Assistant Professor on European and International Labour Law, Leiden University, The Netherlands. International Labor Rights Case Law, 4(1), 128-132. https://doi.org/10.1163/24056901-00401019

The Peninsula. (2017a). Foreign minister says list of demands put to Qatar unrealistic; Germany praises restraint by Doha. The Peninsula.

The Peninsula. (2017b). In Full Text: The speech of Qatar Emir at the opening session of UN General Assembly.

The Peninsula. (2018). Eligibility for permanent residency in Qatar explained in new law. Retrieved from https://thepeninsulaqatar.com/article/04/09/2018/Eligibility-for-permanent-residency-in-Qatar-explained-in- 
new-law

The Peninsula. (2019a). Amir issues law on non-Qatari capital investment.

The Peninsula. (2019b). Cabinet approves draft resolution on determining areas for non-Qatari property ownership. The Peninsula.

Tok, M. E., Alkhater, L. R. M., \& Pal, L. A. (2016). Policy-Making in a Transformative State: The Case of Qatar. Palgrave Macmillan UK : Imprint: Palgrave Macmillan. https://doi.org/10.1057/978-1-137-46639-6

Ulrichsen, Kristian C. (2018). Lessons and Legacies of the Blockade of Qatar. Insight Turkey, 20(2), 11-20. https://doi.org/10.25253/99.2018202.01

Ulrichsen, Kristian Coates. (2017). Implications of the Qatar crisis for regional security in the Gulf. Expert Brief, Alsharq Forum, 29.

Vick, K. (2018). THE AUTOCRAT'S ASCENT: Saudi heir Mohammed bin Salman is pitching his plan to disrupt the Middle East. Time International (Atlantic Edition), 191(14), 24-31.

Vickers, J. (2018). Gulf States'Defence Spending to Hit Record High Amid Ongoing Regional Conflict, Jane's by IHS Markit Says. Jane's Defence Budgets - IHS Markit. Retrieved from https://www.businesswire.com/news/home/20180906005357/en/Gulf-States\%E2\%80\%99-DefenceSpending-Hit-Record-High

Vohra, R. (2017). The Impact of Oil Prices on GCC Economies. International Journal of Business and Social Science, 8(2), 7-14.

Wahyuni, S. (2018). The Impact of the GCC Boycott On Qatar Foreign Policy. Transformasi Global, 4(2).

World Bank. (2017). Migration and Remittances Recent Developments and Outlook: Special Topic on Return Migration. World Bank Group \& KNOMAD. Retrieved from http://documents.worldbank.org/curated/en/719531507124177735/pdf/120240-WP-PUBLIC-3-10-2017-2222-41-MigrationandDevelopmentBrief.pdf

Young, K. E. (2018). The Difficult Promise of Economic Reform in the Gulf. Retrieved from https://scholarship.rice.edu/handle/1911/102812

Zahra, M. (2018). Qatar's Legal Framework of Migration (No. 4/2018). Gulf Labour Markets and Migration GLMM. Retrieved from http://gulfmigration.org/media/pubs/exno/GLMM_EN_2018_04.pdf

\section{Copyrights}

Copyright for this article is retained by the author(s), with first publication rights granted to the journal.

This is an open-access article distributed under the terms and conditions of the Creative Commons Attribution license (http://creativecommons.org/licenses/by/4.0/). 